\title{
Effect of a novel rice fermented extract on gastric ulcers in horses
}

\author{
Naoki SASAKI ${ }^{1 *}$, Yasunobu NISHI ${ }^{1}$, Yumi FUJIWARA ${ }^{1}$, Tetsuya TAKEYAMA ${ }^{1}$, \\ Hayata KUMAGAI ${ }^{1}$, Samantha SENARATHNA ${ }^{1}$, Shigeto USHIYA ${ }^{2}$, Takashi TOKUYAMA ${ }^{3}$, \\ Takahito TOKUYAMA ${ }^{3}$, Takaaki TOKUYAMA ${ }^{3}$, Tomohiro MII $^{3}$, Satomi AYAKI ${ }^{3}$, \\ Kosuke MATSUNO $^{3}$, Yuki NAKAGAWA ${ }^{3}$, Yoshitaka NISHIHARA ${ }^{3}$ and Yasuho TAURA ${ }^{1}$ \\ ${ }^{1}$ Department of Clinical Veterinary Science, Joint Faculty of Veterinary Medicine, Yamaguchi University, Yamaguchi \\ 753-8515, Japan \\ ${ }^{2}$ Ushiya Race Horse Clinic, Shiga 720-3005, Japan \\ ${ }^{3}$ Yushin Brewer Co., Ltd., Kagawa 761-2307, Japan
}

Gastric ulcers cause appetite loss, poor body condition, and colic in horses. This study investigated the protective effect of a rice fermented extract on the gastric mucosa in 17 healthy Thoroughbreds. For one month, horses in the rice fermented extract (nine horses) and control (eight horses) groups were orally administered a rice fermented extract (100\%; $0.2 \mathrm{ml} / \mathrm{kg}$, SID) and tap water $(0.2 \mathrm{ml} / \mathrm{kg})$, respectively. Gastric endoscopic images were obtained before and one month after rice fermented extract administration. The gastric ulcer score was lower after administration (median, 1; maximum, 2; minimum, 1) than

\author{
J. Equine Sci. \\ Vol. 32, No. 2 \\ pp. 27-30, 2021
} before administration (median, 4; maximum, 4; minimum, 3) in the rice fermented extract group $(P<0.05)$. In conclusion, the administration of a rice fermented extract for one month improves gastric mucosal lesions in Thoroughbreds with gastric ulcers.

Key words: gastric ulcer, horse, rice fermented extract

Gastric ulcers cause loss of appetite, poor body condition, and colic in horses. The horse stomach is divided into glandular and non-glandular regions, and it is thought that gastric ulcers occur when gastric acid adheres to the non-glandular region near its fold-like edge, which is the boundary between the two regions $[2,10]$. Studies using gastroscopy have revealed that irregular diet, stress, and exercise decrease the $\mathrm{pH}$ of gastric juice, and approximately $90 \%$ of racehorses and approximately $70 \%$ of riding horses have gastric ulcers $[10,14]$. Currently, therapeutic agents such as $\mathrm{H}_{2}$ receptor antagonists and proton pump inhibitors are used to treat gastric ulcers. However, these drugs need to be administered for long periods (3 to 4 weeks), and continuous prophylactic administration of half the dose

Received: January 7, 2021

Accepted: March 31, 2021

*Corresponding author. e-mail: nsasaki@yamaguchi-u.ac.jp C2021 Japanese Society of Equine Science

This is an open-access article distributed under the terms of the Creative Commons Attribution Non-Commercial No Derivatives (by-nc-nd) License. (CC-BY-NC-ND 4.0: https://creativecommons.org/licenses/ by-nc-nd/4.0/) must be performed even if the gastric ulcer has healed [4, $8,15]$. Therefore, it is necessary to prevent the development of gastric ulcers in horses by adjusting the $\mathrm{pH}$ of the stomach and suppressing gastric mucosal damage. Recently, rice fermented extracts have been reported to prevent ulcer formation and gastric mucosal damage in mice orally administered ethanol or hydrochloric acid and held in cold water to induce stress $[5,11,12]$. Thus, a rice fermented extract is expected to have a protective effect on the gastric mucosa in horses. Therefore, in this study, we investigated the protective effect of a rice fermented extract on the gastric mucosa in Thoroughbreds.

\section{Materials and Methods}

Thoroughbred horses that were moved to a nearby ranch for grazing after running or training at the JRA Ritto Training Center underwent gastroscopy. Of them, 17 horses (mean age $2.9 \pm 0.9$ years; mean weight $468.5 \pm 7.9 \mathrm{~kg} ; 13$ males, 4 females) with gastric ulcer (score of 3 or higher) were used as test subjects. The test animals were bred in stables throughout the experiment. This study was approved 
by the Animal Care Committee of Yamaguchi University.

We obtained the rice fermented extract (Rice Life ${ }^{\mathrm{TM}}$ Extract) from Yushin Brewer Co., Ltd. (Kagawa, Japan). It was prepared by concentrating the culture filtrate dissolved in distilled water produced after saccharized rice was fermented by lactic acid bacteria. The $\mathrm{pH}$ of the extract was 4.50 and its specific gravity was 1.156 . This rice fermented extract was similar composition used in previous studies $[5,9,11,12]$.

The animals were divided into two groups. The horses in the rice fermented extract group (nine horses) were orally administered the rice fermented extract $(100 \% ; 0.2 \mathrm{ml} / \mathrm{kg}$, SID) for one month, while those in the control group (eight horses) were orally administered tap water $(0.2 \mathrm{ml} / \mathrm{kg})$ for one month. The dose of the rice fermented extract was set based on that in the study of Murakami et al. [11], which was effective in rats. Horse groups were randomly divided.

Gastric endoscopic images were obtained before and one month after administration of the rice fermented extract. First, the test horses were fasted for $12 \mathrm{hr}$ before gastroscopy. Next, they were restrained with a nasal twitch, and an animal video endoscope (scope length, 3,000 mm; outer diameter, 8.6 mm; Karl Storz Endoscopy Japan K.K. Co., Ltd., Tokyo, Japan) was inserted through the nostril. Gastric endoscopy was performed along the pleated margin of the stomach from the greater curvature to the lesser curvature, and lesions were observed in the margo plicatus and nonglandular regions. In addition, videos were recorded to observe gastric ulcer lesions in the gastric mucosal epithelium. Gastric ulcer lesions were scored between 1 and 4 according to the system of Andrews et al. [2], as follows: 1 , normal mucosal epithelium or redness and keratinization; 2, small solitary or multiple ulcers of less than $8 \mathrm{~mm}$ in diameter; 3, large solitary or multiple ulcers of more than $8 \mathrm{~mm}$ in diameter; and 4, extensive and often fused ulcers with deep ulceration. The gastric ulcer score was evaluated using the median, maximum, and minimum values. The Mann-Whitney $U$ test was used for statistical analysis to compare the differences between the rice fermented extract and control groups. Statistical significance was set at $P<0.05$.

\section{Results}

On gastroscopy before administration of the rice fermented extract, ulcers were observed mainly in the margo plicatus. There was no significant difference in the baseline median (maximum, minimum) gastric ulcer score between the two groups, with the score being 4 ( $\max , 4$; min, 3) in both groups. In the control group, no significant change was observed in the gastric ulcer lesions before and after the administration of tap water. In contrast, in the rice fermented extract group, the gastric ulcer lesions improved after administration of the rice fermented extract (Fig. 1). In the control group, there was no significant difference in the gastric ulcer score before and after the administration of tap water, with the scores being 4 ( $\max , 4 ; \min , 3)$ and 3 ( $\max , 4$; min, 3), respectively. On the other hand, the gastric ulcer score significantly decreased after administration of the rice fermented extract, with the scores being 4 ( $\max , 4$; min, 3 ) before and 1 ( $\max , 2$; min, 1 ) after administration, respectively $(P<0.05$; Table 1$)$. Thus, the effect of the rice fermented extract on gastric ulcer healing was confirmed.

\section{Discussion}

Thoroughbreds are thought to develop gastric ulcers due to increased gastric acidity caused by stress, training, racing, transportation, feeding of concentrated feed, and restriction of feeding time due to stable feeding $[3,13]$. The most common sites for gastric ulcer reported in a previous study were the margo plicatus and non-glandular regions [7]; ulcers were observed mainly in the margo plicatus and nonglandular regions in this study as well. This may be because the histological composition of these regions is different from that of the glandular mucosa where gastric juice is secreted and because gastric juice with low $\mathrm{pH}$ frequently reaches the non-glandular mucosa, which has low resistance to acid [6]. Even in the non-glandular mucosa, mucosal protection and healing of the injured site occur by mechanisms such as mucus secretion, bicarbonate secretion, epithelial regeneration, and prostaglandin assimilation. However, due to its histological characteristics, it is not adapted to withstand sustained exposure to acidic elements [1]. Therefore, to prevent the onset of gastric ulcers, it is necessary to promote repair of the gastric mucosa damaged by gastric juice. A rice fermented extract has been reported to protect against $\mathrm{NaCl}$-induced rapid mucosal damage and cell proliferation by suppressing replicative DNA synthesis in the rat gastric mucosa [5]. This suggests that a rice fermented extract could effectively protect against acute and chronic gastric mucosal damage. In this study, the administration of a rice fermented extract improved gastric mucosal lesions in horses with gastric ulcers. This may be because the rice fermented extract improved the healing of gastric mucosal epithelial cells. Furthermore, a previous study showed that a rice fermented extract prevented ethanol-induced gastric mucosal and cell damage and improved wound healing in rats [9]. Thus, a rice fermented extract, which is stable when boiled, might be a novel alternative anti-ulcer agent that protects cells and improves wound restoration through vanilloid receptor-mediated neural systems, synthesis of prostaglandins, induction of heat shock proteins, and suppression of gastric acid section. 

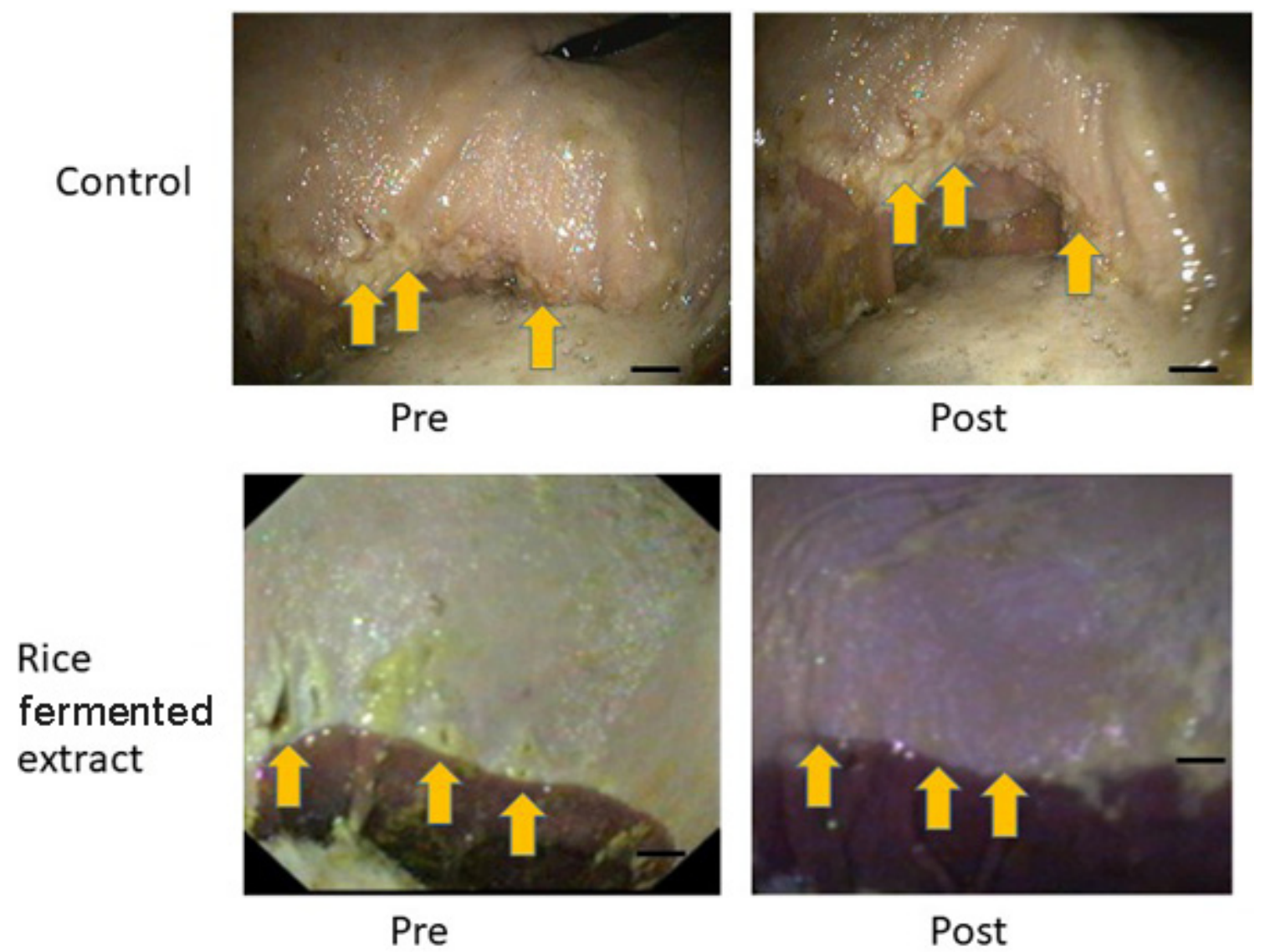

Post

Fig. 1. Gastric endoscopic images before and after administration of the rice fermented extract or tap water. Gastric endoscopic images before (Pre) and one month after (Post) rice fermented extract or tap water administration (Post) are shown. The arrows indicate gastric ulcer lesions. In the control group, no significant change is observed at the lesion site. In contrast, healing of the lesion (repair of the mucosal epithelium) is observed in the rice fermented extract group. Bar: $10 \mathrm{~mm}$.

Table 1. Gastric ulcer scores before and after rice fermented extract or tap water administration

\begin{tabular}{lccccc}
\hline \multirow{2}{*}{ No. } & \multicolumn{2}{c}{ Control } & & \multicolumn{2}{c}{ Rice fermented extract } \\
\cline { 2 - 3 } \cline { 5 - 6 } & Pre & Post & & Pre & Post \\
\hline 1 & 4 & 4 & & 3 & 1 \\
2 & 3 & 3 & & 4 & 2 \\
3 & 3 & 3 & & 3 & 1 \\
4 & 3 & 3 & & 4 & 2 \\
5 & 4 & 4 & & 4 & 1 \\
6 & 3 & 3 & & 3 & 1 \\
7 & 4 & 4 & & 4 & 1 \\
8 & 4 & 3 & & 4 & 1 \\
9 & $/$ & $/$ & & 3 & 1 \\
Median & 4 & 3 & & 4 & $1 * *$ \\
\hline Maximum & 4 & 4 & 4 & 2 \\
Minimum & 3 & 3 & 3 & 1 \\
\hline
\end{tabular}

In the rice fermented extract group, the median score after administration decreased compared with that before administration. On the other hand, in the control group, the median score before administration was not significantly different from that after administration. The gastric ulcer score was significantly lower in the rice fermented extract group than in the control group $(P<0.05)$. $* * P<0.01$.
Horses with gastric ulcers experience loss of appetite [8]; however, this study did not demonstrate an appetiteimproving effect of the rice fermented extract. This is because the loss of appetite in the studied horses was not severe. Future studies on the effect of a rice fermented extract on decreased appetite in horses are needed.

In conclusion, it was revealed that the administration of a rice fermented extract for one month improves gastric mucosal lesions in Thoroughbreds with gastric ulcer. A rice fermented extract may help in the prevention of gastric ulcers in horses by maintaining the homeostasis of gastric mucosal repair.

\section{References}

1. Andrews, F.M., Reinemeyer, C.R., McCracken, M.D., Blackford, J.T., Nadeau, J.A., Saabye, L., Sötell, M., and Saxton, A. 2002. Comparison of endoscopic, necropsy and histology scoring of equine gastric ulcers. Equine Vet. $J$. 34: 475-478. [Medline] [CrossRef] 
2. Andrews, F.M., Sifferman, R.L., Bernard, W., Hughes, F.E., Holste, J.E., Daurio, C.P., Alva, R., and Cox, J.L. 1999. Efficacy of omeprazole paste in the treatment and prevention of gastric ulcers in horses. Equine Vet. J. Suppl. 29: 81-86. [Medline]

3. Coenen, M. 1990. The occurrence of feed-induced stomach ulcers in horses. Schweiz. Arch. Tierheilkd. 132: 121-126 (in German). [Medline]

4. Sutton, D. 2014. Equine gastric ulceration syndrome: treatment and prevention. Vet. Rec. 175: 145-146. [Medline] [CrossRef]

5. Furihata, C., Ishida, S., Ohta, H., Tokuyama, T., Katsuyama, T., and Ogita, Z. 1996. Cytotoxicity of $\mathrm{NaCl}$, a stomach tumor promoter, and prevention by rice extract in stomach mucosa of F344 rats. Cancer Detect. Prev. 20: 193-198. [Medline]

6. Luthersson, N., Nielsen, K.H., Harris, P., and Parkin, T.D.H. 2009. Risk factors associated with equine gastric ulceration syndrome (EGUS) in 201 horses in Denmark. Equine Vet. J. 41: 625-630. [Medline] [CrossRef]

7. Martineau, H., Thompson, H., and Taylor, D. 2009. Pathology of gastritis and gastric ulceration in the horse. Part 1: range of lesions present in 21 mature individuals. Equine Vet. J. 41: 638-644. [Medline] [CrossRef]

8. Mason, L.V., Moroney, J.R., and Mason, R.J. 2019. Prophylactic therapy with omeprazole for prevention of equine gastric ulcer syndrome (EGUS) in horses in active training: a meta-analysis. Equine Vet. J. 51: 11-19. [Medline] [CrossRef]

9. Matsuhashi, T., Otaka, M., Odashima, M., Jin, M., Komatsu, K., Wada, I., Horikawa, Y., Ohba, R., Oyake, J.,
Hatakeyama, N., and Watanabe, S. 2007. Protective effect of a novel rice extract against ethanol-induced gastric mucosal injury in rat. Dig. Dis. Sci. 52: 434-441. [Medline] [CrossRef]

10. Merritt, A.M. 2009. Appeal for proper usage of the term 'EGUS': equine gastric ulcer syndrome. Equine Vet. J. 41: 616. [Medline] [CrossRef]

11. Murakami, M., Ota, H., Sugiyama, A., Ishizone, S., Maruta, F., Akita, N., Okimura, Y., Kumagai, T., Jo, M., and Tokuyama, T. 2005. Suppressive effect of rice extract on Helicobacter pylori infection in a Mongolian gerbil model. J. Gastroenterol. 40: 459-466. [Medline] [CrossRef]

12. Murakami, M., Sugiyama, A., Ota, H., Ishizoe, S., Maruta, F., Sato, T., Akita, N., Kawasaki, S., and Katsuyama, T. 2003. The effect of rice extract on Helicobacter pyloriinfected gastritis in Mongolian gerbils. Ulcer Res. 30: 93-96.

13. Padalino, B., Davis, G.L., and Raidal, S.L. 2020. Effects of transportation on gastric $\mathrm{pH}$ and gastric ulceration in mares. J. Vet. Intern. Med. 34: 922-932. [Medline] [CrossRef]

14. Sykes, B.W., Hewetson, M., Hepburn, R.J., Luthersson, N., and Tamzali, Y. 2015. European College of Equine Internal Medicine consensus statement-equine gastric ulcer syndrome in adult horses. J. Vet. Intern. Med. 29: 1288-1299. [Medline] [CrossRef]

15. Sykes, B.W., Sykes, K.M., and Hallowell, G.D. 2015. A comparison of three doses of omeprazole in the treatment of equine gastric ulcer syndrome: a blinded, randomised, dose-response clinical trial. Equine Vet. J. 47: 285-290. [Medline] [CrossRef] 